\title{
The Usage of Spatial Prepositions in the Headlines of Major Nigerian Newspapers
}

\author{
Bashir Ibrahim ${ }^{1}$, Hamisu Hamisu Haruna ${ }^{2}$, Ibrahim Bashir ${ }^{1} \&$ Kamariah Yunus ${ }^{1}$ \\ ${ }^{1}$ FUniversiti Sultan Zainal Abidin, Gong Badak Campus, 21300, Kuala Nerus, Terengganu, Malaysia \\ ${ }^{2}$ Al-Qalam University Katsina, IBB Way off Dutsin-ma Road, Katsina State of Nigeria, Nigeria \\ Correspondence: Kamariah Yunus, Faculty of Languages and Communication, Universiti Sultan Zainal Abidin, \\ Gong Badak Campus, 21300, Kuala Nerus, Terengganu, Malaysia. kamariah@unisza.edu.my
}

Received: May 23, 2018 Accepted: June 20, 2018 Online Published: November 27, 2018

doi:10.5539/ijel.v8n7p13 URL: https://doi.org/10.5539/ijel.v8n7p13

\begin{abstract}
English language in Nigeria has the status as an official language that is used in local and international correspondences. One aspect of English grammar that is very hard for second language users including Nigerians to master is prepositions. Not only that English prepositions difficult, they are also the most frequently used items in newspapers that play an important role to signal political and cultural discourses. This study aims to describe the usage and communicative functions of spatial prepositions "in, on and at" in the headlines of four major Nigerian newspapers. Primarily, to achieve that the present study adopted Halliday's Systemic Functional Linguistics. Data were collected through the analyses of 21 headlines from four selected major Nigerian newspapers. The findings revealed that Vanguard, a major Nigerian newspaper, has the highest percentage of the usage of target prepositions (26.86\%), seconded by Punch (24.92\%), followed by the Sun (24.27\%), and lastly the lowest percentage, The Nation (23.95\%). Also, it was revealed from the study that newspaper editors preferred to use preposition "at" (indicating specific location) but replaced it with preposition "in" (indicating broader location). Moreover, despite the frequent usage of preposition "in" in replacement of preposition "at", they also preferred the forward position that expresses uncertainty compared to mid-ward and backward positions. This study concludes that people can be united ideologically especially on issues that foster nationalism through the use of newspaper headlines since newspaper headline is a new form of discourse that may initiate, sustain, and shape the political and other national agenda
\end{abstract}

Keywords: spatial, forward, midward, backward and communicative functions

\section{Introduction}

Many second language learners have difficulty understanding the meaning and uses of prepositions, resulting in frequent misunderstanding and wrong interpretations of newspaper headlines. English language has regained a higher status, and it is used widespread in local and international media correspondences (Ibrahim, Shafaatu \& Yabo, 2017). English prepositions are closed item that are ranked among the most frequently used words, and they play an important role in the national discourse (Lee \& Manganhela, 2001; 2016). As second language users, prepositions have always been frequently misused, particularly those referring to time, place, and connection between two objects within the context of transmission. Although English language has been given an emphasis in Nigerian education, little emphasis has been given in the teaching and learning of prepositions and their different meanings (Thompson, 2017). However, there has been a revival of interest in leaning prepositions with respect to the usage in major newspaper headlines (Jackson, 2014). Prepositions also are widely used in literature, technology, judiciary, academic disciplines and also on billboards, minute of the meetings, legal verdicts, treaties, newspapers and advertisements.

\subsection{English Language as Second Language}

English language in Nigeria has the status as a second language and official language. So it has been adopted since the British colonial era, and is used in local and international correspondences. One aspect of English grammar that is very hard for second language users including Nigerians to master is prepositions (Ibrahim, Shafaatu \& Yabo, 2017; Akpabio \& Ogiriki, 2017). Not only that English prepositions are difficult, but they are also the most frequently used items in newspapers that play an important role to signal political and cultural discourses. Ibrahim et al. (2017) stated that Nigerians have difficulty understanding the meaning and uses of 
prepositions, resulting in frequent misunderstanding and wrong interpretations of newspaper headlines. They observed that journalists have their own styles to convey and hide information in newspapers. One of the styles is by manipulating the use of prepositions in major newspaper headlines (Lee \& Manganhela, 2001; 2016).

Similar to other countries, newspapers has become one of the most important sources of information in Nigeria. The effectiveness of written documents including newspaper headlines often depends on accurate arrangements of grammatical structures as well as the semantic and pragmatic functions that the grammatical words aim to convey (Trudgill \& Hannah, 2017; Rashid, Yunus, Wahab, 2016). Nigerian journalists have also adopted the style of conveying and hiding information in newspaper headlines like using prepositions. Henceforth, prepositions are typically difficult as polysemous items with different but relative meanings and senses. According to cognitive semantics, the figurative sense of a preposition is extended from its spatial senses through conceptual metaphors and idiomatic expressions (Yunus \& Auwab, 2016). For example, in table 1 the use of preposition "on" in a phrase "on the prowl" is idiomatic whose meaning is semantically opaque, non-compositional and due to the fuzziness nature of the idioms the meaning cannot be inferred from the words themselves. Therefore, the readers were left to read to get the actual meaning.

Moreover, due to these incorrect usages of prepositions in the headlines; they may confuse readers semantically and pragmatically. The confusion is whether it is the police who killed ten Shiites or the Shiites who killed ten policemen. Pragmatically readers will confuse whether the context is religion or politics. In conclusion, even though prepositional items are small items in the structure of English language, the in correct usage of prepositions may lead to readers' misunderstanding and misinterpretation of newspaper headlines. This may also create religious and political chaos in Nigeria. Also, it is regularly hard to understand the reason why newspapers writers chose certain preposition over others. The same case happens in the four major Nigerian newspaper headlines-Vanguard, Punch, The Sun and The Nation. Prepositions display an array of communicative functions that should be of researchers' interest to study. This paper aims to investigate the functions of prepositions "in, on and at" in the headlines of the four major Nigerian newspapers.

\section{Proliferations}

According to Medwell, Wray, Moore, and Griffiths (2017) as cited Webster New English Dictionary (1976, p.126) whose define preposition as "a word or expression that joins with a noun, pronoun and verb to shape an expression. They are "Relational words that present a prepositional expression. For instance, in the sentence "John is perusing English fiction in the room", the word "in" here is a linguistically, a relational word, presenting the prepositional expression "in the room". A study revealed that the most utilized relational words are of, to, in, for, with, and on (Iatcu, 2011). In that sense, one might say that relational words work as "linkers" between parts of the sentence as well as between all data that are specified in the sentence. They are not limited to importance communicated by noun; rather, they reach out to incorporate those communicated by adjectives words and modifiers (e.g., Wh-questions: who, why, how, when, where, and so forth). Semantically, prepositional word has a linguistic sensation whose qualities could include syntactic, semantic and connected etymological difference from various principles. A few proofs support the idea of structural and communicative functions of prepositions for the political and culture redesign in the speaker's senses, with a different impact and an alternate effect before and after election in the political arena as mentioned by (Taiwo, 2007). Prepositions are commonly use to show a relationship in space or time or a logical relationship between two or more people, places or things and are most commonly followed by a noun phrase or pronoun (Huddleston \& Pullum, 2002).

\subsection{Prepositions}

Prepositions or relational words are part of the smallest word frames; that is, they are static or settled and shut in it is unrealistic to create extra individuals or stretched out to create new ones (Parrott, 2004). They are grammatical form of units used to demonstrate a significant connection that of time, place, instrumental and causal between two substances, one being that spoken by the prepositional supplement' (Quirk \& Greenbaun, 1976). Henceforth, the important relations of time and space are anything but difficult to distinguish and generally found than that causal and best be illustrated in connection to condition. Medwell et al. (2017) characterized relational word as "a word or gathering of words that demonstrate the connections in time, space, or some different faculties between its protest (noun or pronoun that taking after the relational word) and another word in the sentence.

There are two forms of the preposition-simple and complex. According to Essberger (2009), there are more than 150 prepositions in English. 94 of them are simple prepositions and the other 56 are complex. Moreover, the pragmatics forms of preposition, (Yunus \& Awab, 2012) claims that there are 284 different prepositions in English. 88 of them are simple and 160 more are complex. See Table 1 for the list of some simple (single-word) 
prepositions as adapted from Quirk, Greenbaum, Leech and Svartvik (1985).

Table 1. Single-word prepositions (Adopt and adopted from Yunus \& Awab, 2015)

\begin{tabular}{llllll}
\hline About & At & Concerning & in & Outside & To \\
Above & Before & Considering & Inside & Over & Toward \\
Across & Behind & Deposit & Into & Past & Under \\
After & Below & Down & Like & Per & Until \\
Against & Beneath & During & Near & Plus & Upon \\
\hline
\end{tabular}

Simple prepositions alone can have more than one meaning. They are polysemous lexical items (Taylor, 1993) and therefore, can be very confusing. The prepositions in, on, at, to, for, of and from, for example, are prepositions which function to show location, place, direction, and time. An interesting fact about simple prepositions such as on and at is that, they have their own patterns, for example, on Monday and at noon. It is against the convention to replace on Monday with at Monday and at noon with on noon. These are patterns of restriction which occur at a single-word preposition level. Schmitt (2000 cites Allenton \& Carter 1982;1987) consider this patterning as neither grammatical nor lexical collocations but rather the third type of collocation.

\subsection{Positions of Preposition in a Sentence String}

According to Martin Parrott (2004), prepositions usually come immediately before a noun or gerundial. For example, at work or of cooking, at the beginning of a phrase, including a noun (e.g., set-up of, light off) or noun (e.g., interest in). He adds that prepositions can precede a verb (but always in -ing form) (e.g., I am feeling a severe pain). Prepositions can come at the beginning, middle and end of the sentence (Murthy, 2007), for example,

1. at the beginning of a sentence, e.g., from the middle of the year;

2. at the middle of two wards and a sentence; e.g., The spider is on the celling;

3. at the end of the following cause (Murthy, 2007).

\subsection{Functions of Preposition}

Prepositions are joining grammatical words with precisely one supplement state, frequently a noun phrase. In English, this is for the most part a noun called the object of the prepositional words, together with its orderly modifiers. Moreover, a prepositional word builds up the syntactic relationship that links its supplement phrase to another word or expression in the unique situation. In English, it additionally builds up a semantic relationship, which might be spatial (in, on, under, and so on), temporal (after, during), or logical (via, through) in nature. Prepositional word decides certain linguistic properties of its complement (e.g., its case) Okanlawon \& Ojetunde, 2007. In English, the objects of relational words are dependably in the objective case as shown in the Table 2.

Table 2. Functions of prepositions (adopted from Okanlawon \& Ojetunde, 2007)

\begin{tabular}{|c|c|c|c|c|}
\hline $\mathrm{S} / \mathrm{N}$ & $\begin{array}{l}\text { Spatial } \\
\text { Preposition }\end{array}$ & Examples of Headlines & Function & Communicative Function \\
\hline 1. & $\begin{array}{l}\text { Prepositions } \\
\text { Expressing } \\
\text { Positive Position } \\
\text { and Destination } \\
\text { (PPD) }\end{array}$ & $\begin{array}{l}\text { 1. I travelled to Egbeda. } \\
\text { 2. Ade poured water into the cup. } \\
\text { 1. I was at Egbeda. } \\
\text { 2. The water was in the cup. }\end{array}$ & $\begin{array}{l}\text { To express } \\
\text { Destination }\end{array}$ & $\begin{array}{l}\text { These are relational words referring to } \\
\text { development or position in space in } \\
\text { connection to a point or dimension } \\
\text { e.g. at, to and from. It ought to } \\
\text { likewise be noticed that between the } \\
\text { ideas of static position or area and } \\
\text { destination there is a circumstances } \\
\text { and end results relationship. }\end{array}$ \\
\hline 2. & $\begin{array}{l}\text { Prepositions } \\
\text { Expressing } \\
\text { Negative } \\
\text { Position and } \\
\text { Destination } \\
\text { (NPD) }\end{array}$ & $\begin{array}{l}\text { 1. John is away from home }=\text { John is not at home } \\
\text { 2. He is out of the school }=\text { He is not in the school.home }\end{array}$ & $\begin{array}{l}\text { To express } \\
\text { Negative }\end{array}$ & $\begin{array}{l}\text { Adding not to the relating positive } \\
\text { preposition, out of can demonstrate } \\
\text { relational words, for example, off. } \\
\text { There is additionally a circumstances } \\
\text { and end results connection with } \\
\text { negative position and destination. }\end{array}$ \\
\hline
\end{tabular}




\begin{tabular}{|c|c|c|c|c|}
\hline 3. & $\begin{array}{l}\text { Prepositions } \\
\text { Expressing } \\
\text { Relative } \\
\text { Position and } \\
\text { Destination } \\
\text { (RPD) }\end{array}$ & $\begin{array}{l}\text { 1. The plate is on the table } \\
\text { 2. The books are on the shelve } \\
\text { 1. The ball is in front of the table } \\
\text { 2. The house is after main road }\end{array}$ & $\begin{array}{l}\text { To express } \\
\text { Vertical } \\
\text { To express } \\
\text { Horizontal }\end{array}$ & $\begin{array}{l}\text { Prepositions may likewise express } \\
\text { relative position of two objects or } \\
\text { gatherings of objects. Relational } \\
\text { words, for example, above, below, } \\
\text { underneath, over, under and so forth. } \\
\text { they express relative position in a } \\
\text { vertical bearing while in front of, } \\
\text { behind and after express relative. }\end{array}$ \\
\hline 4. & $\begin{array}{l}\text { Preposition } \\
\text { Expressing } \\
\text { Passage (PSP) }\end{array}$ & $\begin{array}{l}\text { 1. He jumped over the wall. } \\
\text { 2. The cat jumped over the wall } \\
\text { 1. The ball passed under the table. } \\
\text { 2. The file passed through my office }\end{array}$ & $\begin{array}{l}\text { To express } \\
\text { Surface } \\
\text { Movement } \\
\text { To express } \\
\text { Through } \\
\text { Movement }\end{array}$ & $\begin{array}{l}\text { The sense of passage or development } \\
\text { is the essential locative meaning } \\
\text { connected to the repositions in this } \\
\text { class e.g. over, by, under, on, over and } \\
\text { through. The movement can be along } \\
\text { a line, over a surface, or through a } \\
\text { space. The movement might be } \\
\text { towards a place, far from a place or a } \\
\text { destination. }\end{array}$ \\
\hline 5. & $\begin{array}{l}\text { Preposition } \\
\text { Expressing } \\
\text { Direction (DIR) }\end{array}$ & $\begin{array}{l}\text { 1. He walked along the road. } \\
\text { 1. He ran across the road. } \\
\text { 2. She goes up and down to see him }\end{array}$ & $\begin{array}{l}\text { To } \\
\text { express } \\
\text { Vertical } \\
\text { direction } \\
\text { To express } \\
\text { Horizontal } \\
\text { expression }\end{array}$ & $\begin{array}{l}\text { These relational words express } \\
\text { progress with reference to a } \\
\text { directional way utilizing verbs of } \\
\text { motions. Up and down to express } \\
\text { vertical heading while along and } \\
\text { across-over express horizontal } \\
\text { direction. With around, the directional } \\
\text { is a terminal point, while towards } \\
\text { signifies the direction.' }\end{array}$ \\
\hline 6. & $\begin{array}{l}\text { Prepositions } \\
\text { Expressing } \\
\text { Orientation } \\
\text { (ORT) }\end{array}$ & He lives in the house down the street. & $\begin{array}{l}\text { To express } \\
\text { Reality or } \\
\text { imagination }\end{array}$ & $\begin{array}{l}\text { These relational words express } \\
\text { introduction from the perspective at } \\
\text { which actually or creative ability the } \\
\text { speaker is remaining (as particular } \\
\text { from a static sense of orientation) e.g } \\
\text { beyond over, up, down and so forth. }\end{array}$ \\
\hline 7. & $\begin{array}{l}\text { Prepositions } \\
\text { Expressing } \\
\text { Pervasive } \\
\text { Meaning (PM) }\end{array}$ & The boy was running all over the garden. & $\begin{array}{l}\text { To express } \\
\text { Pervasive } \\
\text { position }\end{array}$ & $\begin{array}{l}\text { Relational words, for example, over } \\
\text { and through have pervasive meaning } \\
\text { especially when preceded by all. }\end{array}$ \\
\hline 8. & $\begin{array}{l}\text { Prepositions } \\
\text { Expressing } \\
\text { Resultative } \\
\text { Meaning (RM) }\end{array}$ & $\begin{array}{l}\text { 1. I was able to get over the fence. } \\
\text { 2. The man manged to across over the rever }\end{array}$ & $\begin{array}{l}\text { To express } \\
\text { Final } \\
\text { destination }\end{array}$ & $\begin{array}{l}\text { All relational words that have the } \\
\text { significance of movement can } \\
\text { likewise have a static result active } \\
\text { meaning demonstrating the condition } \\
\text { of having achieved the destination. }\end{array}$ \\
\hline 9. & $\begin{array}{l}\text { Prepositions } \\
\text { Expressing } \\
\text { Intended } \\
\text { Destination } \\
\text { (INTD) }\end{array}$ & The man left Kaduna for Lagos. & $\begin{array}{l}\text { To present } \\
\text { Logical } \\
\text { Destination }\end{array}$ & $\begin{array}{l}\text { For, for example, as a phrase of } \\
\text { destination answers the question } \\
\text { 'where ... for?' }\end{array}$ \\
\hline
\end{tabular}

\section{Methodology}

This paper employed mixed method approach for document analysis of two hundred headlines constructed with target prepositions in the four major Nigerian newspapers. The target Nigerian newspapers are Vanguard, The Nation, The sun and Punch that were published July, 2016. To fund the frequent usage of the target prepositions for expressing position which delicate the editor's perceptions in writing headlines. The model instrument for the target prepositions is 200 headlines from Nigerian daily papers that covered the national issues purposively were selected and placed for the analysis.

We found four selected major Nigerian newspapers; Vanguard, Punch, The Sun and The nation is found from 
online source. The target period is from July $1^{\text {st }}$ to September 2016 and 50 headlines each from target newspapers totalled 200 were adequate to address the set objectives. Those headlines are constructed with target prepositions (in, on \& at). Also, the headlines are itemised as found within twenty-one (21) socio-political issues in the nation; insurgency, accident, corruption, rape cases, power tussle, protest, electoral Act, prostitute, national low and order, disaster management, sport issues, business activities, celebrity, politics, education, public enlightenment, social amenities, youth empowerment and health activities. The total of 212 forms of prepositions is found in different zones within 200 headlines. Then the data is tabulated and coded based on percentage and arranged to address the research objectives set in chapter one. The data was sorted to for discussion based on cognitive and systemic functional linguistics perspectives.

Table 3. The Nation (July to December 2016)

\begin{tabular}{|c|c|c|c|c|c|}
\hline $\mathrm{S} / \mathrm{N}$ & Date & Headlines & $\begin{array}{l}\text { Socio-political } \\
\text { Stance }\end{array}$ & $\begin{array}{l}\text { The State of } \\
\text { Preposition }\end{array}$ & $\mathrm{CF}$ \\
\hline 1. & $1^{\text {st July }}$ & Nigerians create records at Rio Olympics & Sports & $\begin{array}{l}\text { "at" is in Btw } \\
\text { D.obj. I.obj }\end{array}$ & Fw \&Bw \\
\hline 2. & $1^{\text {st } J u l y ~}$ & $\begin{array}{l}\text { Customs, FIRS, DPR got N142bn as } \\
\text { incentives in Buhari's 1st yr ... }\end{array}$ & Politics & $\begin{array}{l}\text { "in" is Btw } \\
\text { Adj. and Obj. }\end{array}$ & Midward \\
\hline
\end{tabular}

Finally, the percentage of the finding used, tackled the research objectives 1 . The calculation procedure was done (dividing 100 by total number then multiply by frequent number).

\section{Discussion and Analysis of Data}

\subsection{The Distribution of the Headlines Posts in the Four Major Nigerian Newspaper}

The table below presented the eligibility of the four selected Nigerian newspaper headlines. The data source revealed that English prepositions "in, on and at" in the strings of 200 headlines were adequate for the study objective. The details of the findings of the data are also here tableted below based on the target period.

Table 3. Frequency distribution of the newspaper headlines

\begin{tabular}{|c|c|c|c|c|c|c|}
\hline \multirow[t]{2}{*}{$\mathrm{S} / \mathrm{N}$} & \multirow[t]{2}{*}{ Newspaper } & \multirow[t]{2}{*}{ Headlines Code } & \multicolumn{3}{|c|}{ Constructed Headlines with Target Prepositions } & \multirow{2}{*}{$\begin{array}{l}\text { HTP } \\
\text { Percentage }\end{array}$} \\
\hline & & & Selected NH & Other Related NH & Total & \\
\hline 1. & Vanguard & NH001 & 50 & 199 & 249 & $26.86 \%$ \\
\hline 2. & Punch & NH002 & 50 & 181 & 231 & $24.92 \%$ \\
\hline 3. & The Sun & NH003 & 50 & 175 & 225 & $24.27 \%$ \\
\hline 4. & The Nation & NH004 & 50 & 172 & 222 & $23.95 \%$ \\
\hline & Total & & 200 & 727 & 927 & $100 \%$ \\
\hline
\end{tabular}

Keywords: NH newspaper headline, HTP headlines with target preposition.

In Table 3 above coded the distribution and percentage of the newspapers and their respective headlines. The four major Nigerian newspapers are indicated their ability to answer the research questions within the stated time, based on percentage. The percentage obtained showed that Vanguard newspaper headlines had the highest percentage $26.86 \%$ constructed in the spatial preposition and seconded by the Nation and the lowest with $23 \%$. However, looking at the study area, the percentage can be justified as the spatial prepositions obtain above can satisfy the study needs is in line with Bolton, (2017). Consistently, the distribution information for the target prepositions is also here presented in Table 4 for easy grasp.

Table 4. Distribution of target prepositions

\begin{tabular}{lll}
\hline Prepositions & Frequency & Percentage \\
\hline In & 116 & $54.7 \%$ \\
On & 70 & $33.5 \%$ \\
At & 26 & $12.3 \%$ \\
& $\mathbf{2 1 2}$ & $\mathbf{1 0 0 \%}$ \\
\hline
\end{tabular}


Moreover, Table 4 showed the percentage distribution of target prepositions on the 200 selected headlines of the four major Nigerian newspapers. This was measured based on the appearance of target form of prepositions in the headlines string. The percentage of the data expressed that there is the highest usage of preposition "in" $54.7 \%$ followed by "on" $33.5 \%$ and "at" $12.3 \%$ respectively, as maintained by Astawa, Handayani, Mantra, \& Wardana (2017).

\subsection{Findings and Discussion}

The selected four daily newspapers that published from the month of July to December, 2016 contain 972 related study headlines and utilized 200 to achieve the set objective. The selected two-hundred headlines were placed into deferent categories on four newspapers according to their issues. The target headlines where scarce when compared with other headlines. Moreover, finally through four selected newspapers I cast out headlines with target prepositions "in, on and at", as showed by above tables respectively. The four major Nigerian newspapers were indicated their ability to answer the research question within the stated time, based on percentage.

4.2.1 Objective 1 Is to Examine the Frequent Constructions of the Headlines with the Target Prepositions in the Selected Major Nigerian Newspapers Headlines

The first research question of this study devoted to investigate the frequent construction of headlines with form of prepositions "in, on and at" to examine how frequent usage change or create contradiction to actual details. In regards to Taiwo (2007) that studied language ideology and power relations in Nigerian newspaper headlines basically; he utilised one hundred Nigerian newspaper headlines and were haphazardly chosen from six newspapers then were reviewed for peculiarity in the vocabulary and rhetorical device employed as a part of request to recognize the belief systems that lie behind their developments. In related to that Abba, Olakunle and Musa (2015) also, examined the speech act analysis of Daily Trust newspaper headline reported on Boko Haram attacks. They also used thirty six headlines and were chosen from the Daily Trust newspapers to deliberate irregular investigation and each was assigned to a comparing discourse act classification. Consequently, their review anticipated that constructions of newspaper headlines for insurgency issues are consisted with hidden target ideology for business.

Consequently, Table 3 revealed that headlines constructed with target prepositions were nine hundred and twenty seven in the four major Nigerian newspapers from September to December 2016. However, only fifty articles from each newspaper headlines were selected to make two hundred headlines, which were sufficient to answer the research questions as measured on Table 4 above. Also, therein their communicative functions pinpoint the place and time in between the subject and object of a given sentence.

\subsubsection{Discussion and Analysis for Question 1}

The percentage obtained from Table 3 showed that Vanguard newspaper headlines had the highest percentage $26.86 \%$ constructed in preposition and seconded by the Nation and the lowest with $23 \%$. Furthermore, looking at the study area, the percentage can be justified as the prepositions obtain here above can satisfied the study needs. Also the distribution information for the target prepositions is also presented in Table 4 for easy grasp. Moreover, this was measured based on the use of target form of prepositions in the headlines string. The percentage of the data revealed that there is highest concentration for the usage of preposition "in" $54.7 \%$ followed by "on" $33.5 \%$ and $12.3 \%$ respectively. The stances percentage is also here below on Table 5.

Table 5. Data marge

\begin{tabular}{clcc}
\hline $\mathrm{S} / \mathrm{N}$ & Headlines Stance & Total & Percentage \\
\hline 1. & Insurgency & 51 & $25.5 \%$ \\
2. & Sport & 18 & $9 \%$ \\
3. & Politics & 21 & $10.5 \%$ \\
4. & Education & 9 & $4.5 \%$ \\
5. & Judiciary & 24 & $12 \%$ \\
6. & Accident & 5 & $2.5 \%$ \\
7. & Public Enlightenment & 5 & $2.5 \%$ \\
8. & Celebrity & 6 & $3 \%$ \\
9. & Corruption & 12 & $6 \%$ \\
10. & Business & 24 & $12 \%$ \\
11. & Health & 4 & $2 \%$ \\
12. & Low and order & 9 & $4.5 \%$ \\
13. & Rape cases & 1 & $0.5 \%$ \\
\hline
\end{tabular}




\begin{tabular}{llcc}
\hline 14. & Youth Empowerment & 1 & $0.5 \%$ \\
15. & Disaster Management & 1 & $0.5 \%$ \\
16. & Protest & 4 & $2 \%$ \\
17. & Electoral Act & 1 & $0.5 \%$ \\
18. & Social Amenities & 1 & $0.5 \%$ \\
19. & Power Tussle & 2 & $1 \%$ \\
20. & Prostitute & 1 & $0.5 \%$ \\
& Total & $\mathbf{2 0 0}$ & $\mathbf{1 0 0 \%}$ \\
\hline
\end{tabular}

Primarily, these achievements give a strategic flow to address study question 2 aimed to present the communicative functions played by the form of preposition on the headlines. The stances percentage marge table indicated that insurgency and politics had the highest percentage, based on that the study question two will purposively restricted on them.

4.2.2 Objective 2 Is to Explore the Communicative Functions and Sociopolitical Stances Played by Spatial Prepositions in the Major Nigerian Newspaper Headlines

\subsubsection{Discussion for Headlines on Insurgency Issues}

Nigerians now are experiencing several forms of insurgency issues like other nations in the world which had never happen before. The country was zone by their colonial masters before the independence. The nation divided into five different zones despite their multiplicities of; religious biases, ethnicities and differences in the cultural up-bring. This led obscure among Nigerians and news crew are always ready to found such touching heart news to present on their headlines, as follows

Table 6. Headlines on insurgency

\begin{tabular}{|c|c|c|c|c|}
\hline \multirow[t]{2}{*}{$\mathrm{S} / \mathrm{No}$} & \multirow[t]{2}{*}{ Headlines } & \multicolumn{3}{|c|}{ Form, Position \& Functions of Prepositions } \\
\hline & & Forms & Position & Functions \\
\hline Headline 1 & Sierra Leonean ambassador kidnapped in Kaduna & In & Btw V \& obj & PPD \\
\hline Headline 2 & Jang sponsoring grazing reserve protests in Plateau' Lalong & In & Btw V \& obj & PPD \\
\hline Headline 3 & Kidnappers to face life imprisonment in Delta & In & Btw D.obj \& I.obj & NDP \\
\hline Headline 4 & How woman dumped her son's corpse in canal- witness & In & Btw V \& obj & DIR \\
\hline Headline 5 & 20 killed in Bangladesh cafe attack & In & Btw V \& Sub & ORT \\
\hline Headline 6 & Two IS leaders killed in air strike & On & Btw V \& obj & PPD \\
\hline Headline 7 & Killers on the prowl & On & Btw $2 \mathrm{Sbj}$ & ORT \\
\hline Headline 8 & $\begin{array}{l}\text { Dreaded One MillionBoys kingpins make good their threat unleash } \\
\text { terror on residents }\end{array}$ & On & Btw V \& obj & $\mathrm{RM}$ \\
\hline Headline 9 & Borno: Troops foil attack on displaced persons & On & Btw V \& obj & RPD \\
\hline Headline 10 & Avengers destroys five oil facilities in Delta & In & Btw V \& obj & PPD \\
\hline Headline 11 & Gunmen kill Oyo lawmaker at home & At & Btw 2 obj & NDP \\
\hline Headline 12 & 3hrs gun battle: Troops kill scores of Boko Haram terrorists in Borno & In & Btw 2 obj & PPD \\
\hline Headline 13 & Istanbul attack: FAAN tightens security at Nigerian airports & At & Btw 2 obj & ORT \\
\hline
\end{tabular}

Keywords: (Btw) Between, (V) Verb, (Sub) Subject, (obj) Object, (PPD) Prepositions Expressing Positive Position and Destination, (NPD) Prepositions Expressing Negative Position and Destination, (RPD) Prepositions Expressing Relative Position and Destination, (ORT) Prepositions Expressing Orientation and (RM) Prepositions Expressing Resultative Meaning.

Purposively, Table 5 here above presents 13 out of 51 selected headlines on insurgency issues in Nigerian context. It showed that the constructed headlines mostly retain one form of English preposition "in" to indict trajectory position in landmark. Preposition "in" in the construction did not express precise position as indicated in Table 2 above. Likewise, there are only two headlines in Table 5 that were constructed with verb and noun of insurgency and preceded by the preposition "at" mounted to justify the position of the subject. The reader may need not to ask any question again about exact position of the subject and verb that is "Gunmen, Istanbul, kill and attack". The issue in regard to the subjects "Gunman and Istanbul" as presupposes by Halliday on the ideational tenet that emphasised the world of experience, events and circumstances. Here the reader must be aware or having an experience of the issues in related to the subject and related verb from the previous experience. As the only two headlines categorized below and underline the positioned,

Headline 13 in table 5: Istanbul attack: FAAN tightens security at Nigerian airports. (NH002)

Headline 11 in table 5: Gunmen kill Oyo lawmaker at home (NH001) 
indeed the word "lawmaker" in second headline is clearly coined from the judicial words and the reader's attention will directly relate it to the "court" because whenever a word pronounced, the reader used his gigantic stored data according to their register to sort out meaning as supported by mental function process by Halliday about meaning is generated as sense of idea which is important in the perception of actual experiential meaning. However, the majority of the headlines that were constructed with the preposition "in" is here from among other headlines;

Headline 12: 3 hrs gun battle: Troops kill scores of Boko Haram terrorists in Borno (NH001, NH002)

The subjective element group "3hrs gun battle: Troops" and "kill score of" for the process group, then indirect object "Boko Haram terrorists", prepositional phrase "in Borno" and direct object "Borno". The strings elements and process of insurgencies is for long had a quest of relative position and final destination but they end up with the positive position and destination (PPD). Indeed, for expressing the relative position in a vertical direction usually done by preposition "at" as the case of above headline which will ease the reader to know the relative position and destination (RPD) (Okanlawon \& Ojetunde, 2007) for the insurgency. It should also be noted that between the notions of static position or location and destination there is a textual cause and effect relationship as mention by Halliday.

\subsubsection{Discussion for Headlines on Politics}

The above table presents the political issues in Nigerian newspaper headlines. Most of the nationalist had a full expectation on new a democratic set of government based on their manifestations during the 2015 campaign (Edegoh, 2010). After independence and military regimes, Nigerians adhered to the democratic system of government with a political leader as the president and commander in chief of the armed forces. Consequently, the political gathering for manifestations invites the attention of nationalist and international attention. Therefore, the journalist maintained such avenue to create words fight through various discussions and stages. The newspaper editors utilized the period to explore their technicalities in presenting issues on headlines as above.

Table 7. Headlines on politics

\begin{tabular}{|c|c|c|c|c|}
\hline \multirow[t]{2}{*}{$\mathrm{S} / \mathrm{N}$} & \multirow[t]{2}{*}{ Headlines } & \multicolumn{3}{|c|}{ Form, Position \& Functions of Prepositions } \\
\hline & & Forms & Position & Functions \\
\hline Headline 1 & Photos: President Buhari in Daura, Katsina State for the weekend & In & Btw $2 \mathrm{Sbj}$ & NDP \\
\hline Headline 2 & Mass retrenchment: NLC faction, NUBIFIE insist on picketing banks & On & Btw 2 M. Verb & INTD \\
\hline Headline 3 & Thousands march through London in anti-Brexit protest & In & Btw D.obj \& I.obj & NDP \\
\hline Headline 4 & Referendum: Dubious omission in Nigeria's constitution & In & Btw V \& obj & INTD \\
\hline Headline 5 & Photos: Buhari receives 1953 classmates in Daura & In & Btw $2 \mathrm{Sub}$ & ORT \\
\hline Headline 6 & $\begin{array}{l}\text { Anarchy looms in Abia as third contender emerges, challenges court ruling } \\
\text { affirming Ogah as gov-elect }\end{array}$ & On & Btw 2 Sub & PSP \\
\hline Headline 7 & $\begin{array}{l}\text { If you must probe Fayose, Omisore why not beam same light on Aregbesola, } \\
\text { Oshiomole, Fayemi; PDP tells Buhari }\end{array}$ & On & Btw 2 Sbj & NPD \\
\hline Headline 8 & PHOTOS: Pro-Makarfi PDP group gov campaign begins in Edo & in & Bte V \& obj & PPD \\
\hline
\end{tabular}

During political battles, the newspaper headlines were highly utilized and aimed to spread a wide range of information across the nation and even international, so that to create an influence of voter's attention to support a candidate. Newspaper headlines have been utilised for a wide range of political propaganda to impart information in regards to political aspirations which have been declared powerful in conveying political expectations from the previous government, exploring issues and the way of solving them to the target group (Edegoh \& Anunike, 2016).

Also on politic issues, the system mostly utilized and played a vital role in the Nigerian daily papers headlines. The present study observed that the Nigerian newspapers practitioners indulged in using the backward system so as to pro-certainty in political aspirations as in Vanguard set on headline 9. While the Punch newspaper utilised forward system to inform the public campaign arrangement in Edo state by using present form of intransitive verb "begins". Also, the function of preposition "in" on headline 10 is to indicate the action "campaign" does not have a position in the state and it is just a hot cake information.

Headline 1 table 7 "Photos: President Buhari in Daura, Katsina State for the weekend" (Vanguard April, 2017) 


\section{Headline 10 table 7 "PHOTOS: Pro-Makarfi PDP group gov campaign begins in Edo (Punch April, 2017)}

Henceforth, Headline 9 clearly expresses ideational function where the subject, who is the Nigerian president, passes his weekend clearly. Unlike Punch that contradicted headline 10. Its headline with a forward system, which did not directly, expresses the village and town where the Pro-Makarfi PDP groups are campaigning in the state.

\section{Summary and Recommendations}

The information obtained shows that Vanguard, a major Nigerian newspaper, has the highest percentage on the use of the target spatial prepositions $26.86 \%$ out of 21 issues in the construction of headlines, while the Punch was set up with $24.92 \%$, then the Sun constructed and figured (24.27\%) and the Nation constructed with the lowest figure $23.95 \%$. Moreover, it revealed from the study that the usage of the prepositional form, newspaper practitioners are being neglecting preposition "at" and placed it with "in" to indicate position whether specific or wide location. Indeed, despite using preposition "in" as a replica to "at" they also adopted the forward position to express uncertainty in regards to subject and object. The researcher also observed that on some rare occasions, the people may be united ideologically especially on issues that fosters nationalism. On such occasions, almost all the newspaper headlines are singing the same tune, since they have to reflect the views of the society. Finally, it also reveals that headlines are used to initiate, sustain and shape discourse on the views of readers on national issues.

\section{References}

Abba, T. S., Olakunle, I. A., \& Musa, N. (2015). A speech Act Analysis of Daily Trust Newspaper Headline Reports on Boko Haram Attacks. Prospects, 8(3).

Akeredolu-Ale, B. (2007). Good English for What?: Learners' Motivation as a Factor in Declining Learners' Performance in English Language Acquisition and Use in Nigerian Schools. Changing English, 14(2), 231-245. https://doi.org/10.1080/13586840701443065

Aliyu Kamal. (2001, 2010). English all the way: a primer for intermediate reading and writing skills. Book Ahmadu Bello University Press Ltd., PMB 1094 Samuru, Zaria Nigeria.

Edegoh, L. O., \& Anunike, O. W. (2016). Voters' Assessment of Social Media Use for 2015 Electioneering Campaigns by the two Leading Political Parties in Nigeria. African Research Review, 10(4), 18-40. https://doi.org/10.4314/afrrev.v10i4.2

Essberger, J. (2009). Interjections.

Guralnik, D. B. (1976). Webster's new world dictionary of the American language.

Huddleston, R., \& Pullum, G. K. (2002). The Cambridge grammar of English Language. Cambridge: Cambridge University Press, 1-23. https://doi.org/10.1017/9781316423530

Iațcu, T. (2011). On English Prepositions. Studia Universitatis Petru Maior-Philologia, 10.

Ibrahim, H. A., Shafaatu, M. H. D., \& Yabo, N. U. (2017). English as a Medium of Instruction: Challenges to Nigerian Primary Schools. The Victorian, 5(2).

Jackson, H. (2014). Words and their Meaning. Canadian Social Science, 9(4), 78-84. Retrieved from https://books.google.com.ng/books?isbn=1317887573

Kamalu, I., \& Tamunobelema, I. (2013). Linguistic Expression of Religious Identity and Ideology in Selected $\begin{array}{lllll}\text { Postcolonial Nigerian Literature. Canadian Social Science, } 9(4), & \text { 78-84. }\end{array}$ https://doi.org/10.4324/9781315842004

Medwell, J., Wray, D., Moore, G., \& Griffiths, V. (2017). Primary English: knowledge and understanding. Learning Matters.

Murthy, K. N. (2007). Statistical Analyses of Myanmar Preposition Corpora. Technical unpublished report, Department of Computer and Information Sciences, University of Hyderabad. 26 March.

Okanlawon, B., \& Ojetunde, B. A. (2007). A Study of the Acquisition of Spatial Prepositions by Selected Nigerian Learners of English. African Research Review, 1(3), 96-107.

Okoro, C. N. (2017) A Speech Act Analysis of the Formal Declaration of Interest for Presidency and Inaugural Speeches of President Muhammadu Buhari.

Parrott, R. (2004). Emphasizing "communication" in health communication. Journal of Communication, 54, 
751-787. https://doi.org/10.1111/j.1460-2466.2004.tb02653.x

Quirk, R., \& Greenbaum, S. (1970). Elicitation Experiments in English: Linguistic Studies in Use and Attitude. London: Longman.

Rashid, R. A., Yunus, K., \& Wahab, Z. (2016). Deconstructing functional organisation of newspaper discourse. International Journal of Applied Linguistics and English Literature, 5(6), 183-189.

Simaki, V., Simakis, P., Paradis, C., \& Kerren, A. (2017). Identifying the Authors' National Variety of English in Social Media Texts. In The 11th Biennial Conference on Recent Advances In Natural Language Processing (RANLP'17), 2-8 September 2017, Varna, Bulgaria. https://doi.org/10.26615/978-954-452-049-6_086

Taiwo, R. (2001). Thematic Structure of English-Medium Nigerian Newspaper Reports. Ife Studies in English Language, 5.

Taiwo, R. (2004). Speech as Headline in Nigerian Newspapers. In Awonusi, S.

Taylor. (2008). Transformative learning theory. New directions for adult and continuing education, (119), 5-15. https://doi.org/10.1002/ace.301

Thompson, E., Varela, F. J., \& Rosch, E. (2017). The embodied mind: Cognitive science and human experience. MIT press. https://doi.org/10.7551/mitpress/9780262035668.003.0005

Vaccarelli, F. (2010). English in West Africa: the Case of Nigeria. English, But Not Quite: Locating Linguistic Diversity, $1,155$.

Yunus, K. B., \& Awab, S. (2011). Collocational competence among Malaysian undergraduate Law students. Malaysian Journal of ELT Research, 7(1), 151-202.

Yunus, K., \& Awab, S. A. (2012). The Effects of the Use of Module-based Concordance Materials and Data-driven Learning (DDL) Approach in Enhancing the Knowledge of Collocations of Prepositions among Malaysian Undergraduate Law Students. International Journal of Learning, 18(9). https://doi.org/10.18848/1447-9494/CGP/v18i09/47758

Zajic, D., Dorr, B., \& Schwartz, R. (2002, July). Automatic headline generation for newspaper stories. In Workshop on Text Summarization (ACL 2002 and DUC 2002 meeting on Text Summarization). Philadelphia (p. 65).

\section{Copyrights}

Copyright for this article is retained by the author, with first publication rights granted to the journal.

This is an open-access article distributed under the terms and conditions of the Creative Commons Attribution license (http://creativecommons.org/licenses/by/4.0/). 